\title{
From English to First-Price Sealed Bid: An Empirical Assessment of the Change in Auction Type on Experienced Bidders
}

\author{
Joshua J. Miller ${ }^{1}$
}

\begin{abstract}
This paper estimate the differential impact of first-price sealed-bid (first-price) auctions relative to English auctions on auction revenue. While there is a theoretical literature on the potential outcomes of first-price relative to English auction, there is a paucity of articles that empirically estimate this relationship. The answer to this question is important not only to economists but also those designing auction for practical application. Using a unique dataset from tax lien auctions in Illinois, I empirically test the effect of a switch in auction type from English to first-price. I find auction revenue is greatly increased, by as much as 22 percent, under the first-price auction. The results are supported by a within county difference-in-difference model specification and are robust when restricting the sample across various specifications.
\end{abstract}

Key words: Property Tax Delinquency, Tax Lien Sales, Auction Type, Auction Design

JEL Classification: H71, D44

\section{Introduction}

Auctions are important. In the United States, auctions are used to sell national debt, spectrum (airwave rights), pollution rights (Kagel and Levin, 2002), and property tax delinquency. The most common types of auctions used are English and first-price sealed-bid (first-price). While heavily utilized, the difference in outcomes between English and first-price is not well understood. More particularly, it is unclear whether sequential common value first-price auctions produce more revenue for sellers compared to English auctions. Theoretical models predict (McAffee and McMillan, 1987) and experimental results find (Kagel and Richard, 2001) increased revenue for sellers under the first-price auction. This effect arises because unlike English auctions, bidders cannot observe market signals under first-price auctions, and as a result they overpay. Revenue differs between auction types because of differences in the ability to observe market signals.

My analysis is the first to empirically confirm prior theoretical prediction and experimental results by using administrative data. Using a unique dataset from one of the

\footnotetext{
${ }^{1}$ Housing Policy Economist, NAHB, Washington, DC 20005, 1-202-266-8398, Fax: 1-202-2668575 ,jmiller@nahb.org. The views expressed are the author's and may not be attributed to NAHB. The author would like to thank Jan Jonas and two anonymous referees for their invaluable comments.
} 
largest annual tax lien auctions in the country, I estimate the effect of a switch from English to first-price auction. I observe a switch from English to first-price auction in Cook County, Illinois. The switch was implemented to reduce the number of days needed to conduct the sale, rather than altering winning bids. In this paper, I rely on the fact that first-price auctions were conducted over four rounds. In the first-price auction, bidders observe no market signals in the first round, but they do observe market signals in the subsequent rounds. The market signals in the first-price auction improve as rounds progress and I argue that they approach the English auction environment after a large number of rounds.

The dataset allows me to estimate the effect of a switch from English to first-price auction on winning bids using a difference-in-difference model specification. The treatment group is liens auctioned in the first round of both English and first-price auctions. The control group is liens offered in later rounds of the first-price and English auctions. The differencing within auction type differences out potential unobserved confounders such as the price decline anomaly (Ashenfelter, 1989). The price decline anomaly is the phenomenon in which identical products sold sequentially typically follow a decreasing pattern of prices (McAffee and Vincent, 1992). The between auction type differencing identifies the effect of not observing market signals on winning bids under first-price relative to English auction. This strategy resolves any selection issues that arise from auction choice, since my identification does not rely on simple pre-post comparisons. Furthermore, I avoid any biases in estimation that arise due to timing of auction adoption.

I find higher prices in the first round of the first-price auctions compared to the control group. For the unrestricted sample, which includes all rounds of first-price and English auctions, prices are 22 percent higher in the first round of the first-price auction. The results are robust when controlling for the probability of sale and are not sensitive to restrictions to the sample based rounds or years. My analysis confirms prior theoretical predictions and experimental results that suggest that first-price auctions produce higher revenue for sellers.

The analysis represents a contribution to the literature and advances the understanding of auction design. This empirical analysis is the first to addresses selection through a difference-in-difference model specification. The data allows for the identification of switching from English to first-price both across time and within auction. Although Meade (1967) found that first-price auctions resulted in significantly higher winning bids on the sale of timber by federal and state government, the findings was unsettled in the empirical literature due to concerns with selection. The empirical analysis confirms the prior result while addressing concerns of bias due to selection.

\section{Tax Liens, Bidder Characteristics, and Auction Rules}

A tax lien auction is the sale of delinquent property taxes by a local government to investors. When a property taxpayer becomes delinquent, a local government places a lien against the property. The lien represents a collateralized receivable but not direct ownership of the property. In a tax lien sale, investors pay the delinquent property tax bill to the government. In return, investors receive the lien and the right to repayment of the delinquent taxes plus interest. 
In 2012, local governments in 28 states conducted tax sales offering an estimated \$6 billion in delinquent tax liability. ${ }^{2}$ Tax liens sold by local governments are purchased predominantly by large investment firms who pool thousands of liens into investment products which are resold to smaller investors. Large tax lien investors are experienced bidders, participating in numerous auctions yearly across multiple states.

Liens are of common value to bidders because the monetary benefit of lien ownership, which is unknown at the time of bidding, does not vary across bidders. An example of a common value auction, is that of an oil reserve for an unproven well (Menezes and Monteiro, 2005). The value of the oil reserve depends on the price of oil which is known by potential bidders. The value of the oil also depends on the amount of oil in each well which is estimated by potential bidders prior to the start of the auction. In a tax lien auction, similarly, the value of the lien depends on factors known by all bidders, the structure of repayment and application of interest fees. The value of a lien also depends on the timing of repayment which is estimated by bidders.

The tax lien auction I observe is commonly referred by industry participants to as an interest rate auction. Tax lien investors bid on individual liens by declaring an interest rate between 18 and zero percent. Bids are entered in whole percentage point increments (i.e. 18, 17, 16, and 15). The bidder with the lowest interest rate wins the right to pay the delinquent property taxes in exchange for repayment plus interest fees. The lien is transferred to the winning bidder as collateral. Interest rate bids of 18 percent represent a low price for bidders in which case the winning bidder will earn an 18 percent return on investment during the first year of delinquency. Interest rate bids of zero percent represent a high price in which case the winning bidder will earn no return on investment during the first year of delinquency. Liens are offered in sequential order one parcel at a time by volume and property identification number (PIN). Liens not receiving a bid at auction are returned to the county for collection with the delinquent taxpayer charged an interest fee of 18 percent during the first year of delinquency.

In the auctions, bidders face different auction types depending on the year. Of the four auction types commonly discussed in the literature (Klemperer 1999), I observe an English auction and a first-price auction. In the English auction, bids are submitted by raising a paddle. The English auction of the tax lien concludes when only one bidder remains or multiple bidders with matching interest rates are unwilling to bid at a lower interest rate. When more than one bidder offers the same low bid, the county treasurer chooses a winner at random. Bidders are able to observe market signals.

The first-price auction differs further from the English auction in two ways; the treatment of matching bids and the utilization of bidding rounds. In the first-price auction bids are not randomly awarded by the county, except for liens receiving multiple bids of zero percent. Rather, liens receiving matching bids are held by the county and reoffered at a later date. In the first-price auction, liens are offered in four rounds based on the property identification number. In the English auction, liens are not offered by rounds.

\footnotetext{
${ }^{2}$ Source: Vulture Investing: What You Need To Know Before Bidding For Tax Liens - Forbes November 26, 2012
} 
The first-price auction design observed deviates from the standard first-price in utilizing four rounds whereas the standard first-price design auctions items all at once. A potential concern is that the observed auction rules, which are known in advance, may lead to bidding strategies that deviate from the standard first-price auction design.

To mitigate, the concern of multiple rounds, the treatment group chosen is the first round of the observed first-price auction rather than the entire first-price auction. The first round of the first-price auction most closely replicates the standard first-price auction design. Further, in laboratory settings even super-experienced bidders have been shown to adjust bidding strategies as successive first-price auction are conducted (Kagel and Richard, 2001). This suggests the first round of the first-price auction is the appropriate treatment group.

The effect of tie-breaking rules deserves further discussion as well. In general, two possible rules are employed. The first breaks ties at random perhaps by flipping a coin or randomly assigning a winner by a predetermined algorithm. The second possible rule allows ties to be broken with another round of competitive bidding. It is not clear which rule should be viewed as the standard approach for the first-price auction.

Although tie-breaking rules effect winning bids in English auctions (Milgrom, 2004), no evidence exists showing tie-breaking rules effect winning bids in the first-price auction. Further, in the absence of market signals, such as the first round of the observed firstprice auction, bids are submitted according to the bidder's expected payoff function. In the first-price auction, the tie-breaking regimes discussed do not change the bidder's expected payoff function. Instead a submitted bid above the expectation would result in overpayment. A bid submitted below the expectation may result in losing to competitive bidders.

\section{Literature Review}

The theoretical literature examining the effect of auction type on the type of auction is extensive (Milgrom and Webber 1982; McAffee and McMillan, 1987). The theoretical models predict first-price sequential common value auctions result in higher revenue for sellers than English sequential common value auctions (McAffee and McMillan, 1987). The primary difference between English and first-price auction is one of information. In first-price auction participants do not have access to market signals until the auction is complete. The bidder with the most optimistic valuation wins the item. In the English common value auction, bidders correct their estimates based on market signals. The winning bid in the English auction is the Nash equilibrium (Kagel and Levin, 2002).

The Handbook of Experimental Economics provides an exhaustive discussion of the experimental auction literature. One bidding issue consistently observed in the laboratory setting that is of particular relevance to this study is the "winner's curse" (Kagel, 1995). In a common value auction, winners are those with the most optimistic expectations. The expectations of the winner are often wrong resulting in below average or even negative profit.

In laboratory experiments, the "winner's curse" is especially pervasive in the first round of a first-price auction where market signals are not observed. Inexperienced bidders have been shown to consistently overbid in a wide variety of auction settings 
(Lind and Plott, 1991). The results are also observed for super-experienced bidders in laboratory settings (Kagel and Richard, 2001). Super-experienced bidders are bidders who participated in two or more auction sessions.

The implication is that in controlled experiments market signals are important because it allows overly optimistic bidders to correct their expectations. Further, laboratory results show first-price auctions yield higher revenue to sellers when compared to the English auction. Kagel and Richard (2001) find super-experienced bidders earn less than 50 percent of the Nash equilibrium profits under a first-price auction.

Empirical examination of the topic is less common. Mead (1967) was the first to empirically estimate the difference in winning bids between otherwise similar auction designs using English and first-price. He found that first-price auctions resulted in significantly higher winning bids on the sale of timber by federal and state government. Upon further examination, however, Hansen $(1985 ; 1986)$ found that although first-price auctions produced higher winning bids than otherwise similar English auctions, the results were not statistically significant due to a selection bias. Hansen found evidence to suggest the difference in revenue observed across auction type by Mead (1967) was correlated with the U.S. Forest Service's choice of auction type.

Although theoretical models predict (Milgrom and Webber, 1982; McAffee and McMillan, 1987) and laboratory experiments (Kagel and Richard, 2001) demonstrate the firstprice auction generate more revenue than an otherwise similar English auction, no empirical studies confirm the results on administrative data. In this paper, I find support for the theoretical results using administrative data on auctions of liens. The paper avoids the selection bias by using a unique dataset whereby the choice of auction type is not correlated by auction revenue. Additionally, in using the difference-in-difference estimator, I avoid selection issues correlated with the timing of the change in auction type. I find that first-price auctions do produce higher prices for bidders and higher revenue for sellers.

\section{Data Sources and Variable Construction}

In order to estimate the effect of a switch from English to first-price on winning bids, I obtained data for this study from the Cook County Treasurer. The data includes liens offered for property within the city of Chicago. From 2006 to 2011, I observe two English auctions and four first-price auctions. The data include information on liens offered, liens sold, winning bids, delinquent tax bill, assessed value, property type, auction order, property location, and buyer name. Tables 1,2 , and 3 provide descriptive statistics.

Table 1 shows descriptive statistics of sold and unsold liens by auction design. The table highlights that the majority of sold liens were for residential improved property (property with single family or multifamily homes) under both designs, while the majority of unsold liens were commercial improved, industrial improved or vacant properties. The mean delinquent tax bill and share of unsold liens on residential improved property were higher under the first-price auction.

Table 2 shows the count and percent of liens sold, the dollar value and percent of property tax delinquency sold, and mean and median interest rates by auction design. The Cook County Treasurer sold to investors approximately 85 percent of all liens offered 
and 85 percent all dollars offered to investors under the English auction. However, only 71 percent of all liens offered and 75 percent of all dollars offered to investors sold under first-price sealed auction. Across both auction types, winning bids ranged from zero to 18 percent. The median winning bid was zero under the English auction and three percent under the first-price auction.

Table 3 shows that the overwhelming number of liens and dollar value of liens are purchased by large investors purchasing 100 or more liens at any one auction regardless of auction type. The mean winning interest rate and mean delinquent tax bill vary by the buyer size however no obvious pattern exists across auction designs. Buyer fixed-effects are generated and included in the empirical model to control for these differences.

The differences observed in table 1,2, and 3 are due to several factors. The first is timing, whereby winning interest rates differ across periods for unobserved reasons (i.e. tax lien investor sentiment). The second is the type of liens offered differs across periods (i.e. higher share of residential property, more liens in a particular tax district). The final factor, and the focus of this study, is auction type differs across periods. In order to disentangle each factor the empirical strategy implemented is a difference-in-difference model specification that control lien characteristics. This strategy allows for the identification of the effect of changing auction type on winning interest rates.

The dependent variable is not normally distributed. Although a logarithmic transformation of the dependent variable (Manning and Mullahy, 2001) would address issues of non-normality of the data, this is not possible due to the existence of winning interest rates at zero percent. This would lead us to data truncation issues, and we do care about whether different auction rules lead to winning bids with a zero interest rate.

Although local governments in Illinois have used tax lien sales since 1819 (Carlson 1951; Swierenga 1974), researchers know little about the responsiveness of bidders to different auction types. No study to date estimates the effect of auction type on winning bids for tax lien auctions.

Previous literature examined determinants of winning bids in tax lien auctions. Because local governments place a lien against property, tax lien investors use property characteristics to determine bids. In a survey of 160 tax lien investors, respondents listed estimated market value, property type, and location as the most important factors influencing bids (DeBoer and Conrad, 1990). Two empirical studies (DeBoer et al., 1992; Allen et al., 2004) confirm the survey and also find delinquent tax bill, auction order, and buyer characteristics determine winning bids. I control for these previously identified determinants to isolate the effect of auction type on winning bids. Below I provide variable definitions.

Assessed value serves as a proxy for estimated market value (DeBoer et al., 1992). The assessment ratio in Illinois is one-third. Therefore, I compute the estimated market value by multiplying assessed value by three. I control for inflation by converting the estimated market value for each property to 2011 dollars.

The minimum bid is the delinquent tax bill for each lien, since winning bidders must pay the delinquent tax bill for each lien won. High minimum bids are shown to reduce auction revenue (Milgrom, 2004). I control for inflation by converting the delinquent tax bill for each property to 2011 dollars. 
Property type informs bidders on the expected payoff of the tax lien offered (DeBoer et al., 1992). All else equal, liens against residential improved property have higher expected payoffs than liens on other property types. Residential improved liens are more likely to be redeemed and in the case of non-redemption easier to sell. I separate property type in this dataset into three mutually exclusive categories. The first property type is residential improved, which represents approximately two-thirds of all observation. Residential improved property includes one-family dwellings, multi-family dwellings, condo-units, and apartment buildings. The second property type is vacant property, representing less than one-quarter of all observations. The third property type is all other improved property, which includes commercial improved and industrial improved. I run the analysis and use other improved property is the excluded benchmark.

Property location also informs the bidders on the expected payoff of the tax lien offered (DeBoer et al., 1992). All else equal, liens located in higher quality neighborhoods have a higher expected payoff than liens located in lower quality communities (DeBoer and Conrad, 1990). I control for property location, and therefore neighborhood quality, using the tax district in which each property located. In Illinois, counties separate into smaller geographic units called tax districts, which are responsible for the assessment of property value for tax purposes. Cook County has 33 tax districts.

Tax lien sale investors vary in the number of liens purchased, types of liens purchased, experience, and access to capital (DeBoer and Conrad, 1990). Previous research (Allen et al., 2004) finds that large volume investors, those purchasing 100 or more liens at any one auction, purchase at lower interest rates. Liens are almost exclusively purchased as an investment vehicle for large buyers, who generally purchase hundreds of liens. In Cook County, for example, from 2006 to 2011, 97 percent of liens where sold to large investors purchasing 100 or more liens at any one auction as shown in table 3 .

To account for bidder characteristics that affect winning bids, I normalize the names of buyers across auctions. For example, Praticorp Incorporated purchasing liens in the 2007 tax lien sale was treated as the same Practicorp purchasing liens in the 2008 tax lien sale. There were a total of 282 unique buyers in the dataset. Next, I rename all bidders participating in only one auction and winning only one lien novice bidders. There are a total of 77 novice bidders in the dataset. I run the analysis and using novice buyers as the excluded benchmark.

Normalizing buyer names is necessary to establish buyer fixed-effects. Buyer-fixed effects control for unobserved variation specific to each winning bidder. Whereas the previous literature controls for bidder-specific differences based on the number of liens purchased, this method is only able to identify the size of buyers, but not specific buyers. The previous literature assumes that all large buyers behave similarly, but it does not allow for buyer specific variation. My identification strategy is an improvement because it controls for unobserved buyer characteristics that could affect auction outcomes and bidding strategies.

\section{Identification Strategy}

The switch in auction type by the Cook County Treasurer provides the best opportunity to generate an unbiased estimate of the effect of a switch from English to first-price auction on winning bids. The county treasurer switched to first-price auction in 2008 to 
reduce the total number of days needed to conduct the sale, not to alter winning bids. In fact, the county receives the same revenue whether the lien is sold at a high price of zero percent or a low price of 18 percent. In 2007, while using the English auction, the treasurer offered nearly 17,000 liens in 16 days. In 2008, while using the first-price auction, the treasurer offered nearly 27,000 liens in 5 days.

Although the decision to switch auction type was motivated by the treasurer's desire to reduce the number of days and not to alter winning bids, an OLS regression comparing results between the English and first-price auctions produces estimates biased by the timing of adoption. The treasurer switched to the first-price auction during the housing market collapse. A simple comparison of means shows that average winning bids are lower under the English auction before the housing market collapse, than under the firstprice auction after the housing market collapse. The difference in winning bids is a combination of the change auction type and the timing of adoption.

A common technique implemented to deal with this potential bias is a difference-indifference identification strategy. The difference-in-difference strategy is not possible across Illinois counties as a credible control group does not exist for Cook County. Kane County, a large suburban Illinois county, is the only suburban county bordering Cook County from 2006 to 2011 to use the same English auction design found in Cook County prior to the switch. Although Kane County appears to be a credible control group, spurious auction results were observed over the time period. As shown in figure 1 , the mean winning bid in Kane County increased from 2.5 percent in 2006 to 15.5 percent in 2007. During the same period using the same auction design the mean winning bid in Cook County decreased from two percent in 2006 to 1.4 percent in 2007.

In 2007,83 percent of liens sold in Kane County were sold at the maximum interest rate of 18 percent. Previous literature (Milgrom 2004) suggests the results are due to inefficient rules on matching whereby competition amongst investors is not rewarded. The odd auction result could also be the result of collusion (Department of Justice, 2011). Regardless of the cause, the trend in tax lien auction results for Kane County was very different than those in Cook County over the same time period. The unexplained difference is one reason why Kane County does not represent a credible control.

Additionally, neighboring counties are not a credible control because Cook County tax lien investors do not participate in the neighboring county auctions in large numbers. During the period of observation only 21 winning bidders participating in Cook County tax lien sales also participated in at least one tax lien sale in neighboring counties. These bidders purchased 56 percent of all liens sold in Cook County, but only 9 percent of liens sold in the neighboring counties. The final reason neighboring counties are not a credible control is that Cook County sells liens with six month of additional delinquency when compared to other Illinois counties. Cook County is selling a slightly different investment product.

A difference-in-difference identification strategy is possible within Cook County because in the first-price auction observed, liens are offered in four rounds. Investors submit sealed bids on individual liens within each round. For the first round, investors submit bids absent market signals. After the first round is completed, bidders are informed of liens won. If a lien is won with a bid between one and 18 percent, the winning bidder knows for certain their valuation of the lien is the highest of all bidders. If the lien is not 
won with a bid between one and 18 percent, the bidders knows for certain their valuation is not uniquely the highest valuation. Winning bids of zero percent submitted by a bidder are the result of either a valuation higher than all bidders or the random assignment of the lien based on multiple zero percent bids. Losing bids of zero percent submitted by a bidder are the result of random assignment of the tax lien to a competing bidder also submitting a zero percent bid.

When the second round begins, investors submit sealed bids on individual liens based on independent valuations and market signals from the first round. When the third round begins, investors submit sealed bids on individual liens based on independent valuations and market signals from the first and second rounds. When the fourth round begins, investors submit sealed bids on individual liens based on independent valuations and market signals from the first, second, and third rounds.

Table 4 shows average winning bids of all liens offered by auction type, round, and year. Average winning bids differ by round under the first-price auctions because of property characteristics, price-anomalies (Ashenfelter, 1989; Ashenfelter and Genesove, 1992; Mezzitti, 2011), and the ability of bidders to observe market signals. Average winning bids differ by round under the English auction because of property characteristics and price-anomalies. Average winning bids do not differ by round under the English auction because bidders are able to observe market signals when the first lien is offered. In the English auction, bidders observe market signals which include number of competitors, submitted bids, and winning bids. The ability of bidders to observe market signals does not depend in the English auction on the constructed round.

For the English auctions, I assign liens to rounds based on volume number. The assignment is consistent with the assignment of liens under first-price auctions. Volume numbers are assigned to each property based on the location of the property by the county. Liens are offered in sequential order one parcel at a time by volume and property identification number (PIN) within volume. The assignment of volume numbers and PINs are constant over time. Therefore, had the liens sold under the first-price auction instead of English auction the round assignment would have been the same.

More explicitly, liens are auctioned by volume number. In the first-price design, liens with volume numbers 001 to 147 are auctioned in the first round. Liens with volume numbers 148 to 270 are auctioned in the second round. Liens with volume numbers 271 to 464 are auctioned in the third round. Liens with volume numbers 465 to 601 are auctioned in the fourth round.

Because the volume number for all liens is provided, it is possible to assign rounds to liens offered under the English design. For example, a lien offered under the English design with the volume number 006 would have been offered in the first round of the first-price auction because the volume number falls within the range 001 to 147 .

$\begin{array}{llll}\text { If } & 001<\text { Volume Number }<147 & \text { then } & \text { Round } 1 . \\ \text { If } & 148<\text { Volume Number }<270 & \text { then } & \text { Round } 2 . \\ \text { If } & 271<\text { Volume Number }<464 & \text { then } & \text { Round } 3 . \\ \text { If } & 465<\text { Volume Number }<601 & \text { then } & \text { Round } 4 .\end{array}$


The following notation is used to describe the average winning bids under each auction type for each round:

$\bar{l}_{E}^{n} \quad$ : Average winning bid, English auction, round $\mathrm{n}$

$\bar{l}_{f}^{n} \quad$ : Average winning bid, first-price auction, round $\mathrm{n}$

In the auctions observed, bidders face two possible environments. The average winning bids in both environments is a function of property characteristics, price-anomalies, and market signals. In the first environment, where $\mathrm{T}=0$ or the control, bidders observe market signals. The control group is liens sold under the second through fourth rounds of English and first-price auctions. In the second environment, where $\mathrm{T}=1$ the treatment, bidders observe no market signals in the first-price auctions, but these market signals are observable in the English auction. The treatment group is liens sold in the first round of the English and first-price auctions.

By assumption, the quality of market signals observed by bidders does not vary in the English auctions by constructed round. However, the quality of market signals observed by bidders improves in the first-price auction after each round. Therefore, the average winning bid in the first-price auction approaches the average winning bids in the English auction as the number of rounds increase. Equation (1) shows the relationship between average winning bids across auction type and round.

$$
\lim _{n \rightarrow \infty} f\left(\bar{l}_{f}^{n}\right)=\bar{l}_{E}
$$

Therefore, average winning bids in the first-price auction, where $\mathrm{T}=0$ and $\mathrm{n}>1$, approach the average winning bids in the English auction, where $\mathrm{T}=0$ and $\mathrm{n}>1$, as given in equation (2).

$$
E\left[l_{f}^{n>1} \mid T=0\right] \cong E\left[l_{E}^{n>1} \mid T=0\right]
$$

The difference-in-difference methodology differences within auction. For the English auction, the first difference is that between treatment and control as given below in equation (3).

$$
\Delta l_{E}=\bar{l}_{E 1}-\bar{l}_{E 2-4}=E\left[\bar{l}_{f}^{n=1} \mid T=1\right]+E\left[\bar{l}_{f}^{n=2-4} \mid T=0\right]
$$

Since there is no difference in market signals between treatment and control for the English auction, the first difference accounts for potential unobserved confounders (i.e. price anomalies).

Similarly, the first difference for the first-price is that between treatment and control rounds as given by equation (4).

$$
\Delta l_{f}=\bar{l}_{f 1}-\bar{l}_{f 2-4}=E\left[\bar{l}^{n=1} \mid T=1\right]+E\left[\bar{l}^{n=2-4} \mid T=0\right]
$$

Equation (4) differences out both potential confounders and market signals that are not present in round one but present thereafter.

The second difference then differences the differences, such that the remainder is that of market signals. The second difference is given in equation (5).

$$
\delta=\Delta l_{f}-\Delta l_{E}=\text { market_signals }
$$


So long as the unobservables do not differ between first-price and English auction, the remainder is the difference in market signals between the English and first-price auction.

To empirically test whether the difference is statistically different from zero, I use the basic regression model shown in equation (6). The purpose of the model is to isolate the effect of market signals on average winning bids, and therefore the average treatment effect of switching from English to first-price on winning bids.

Interest $_{l t}=\beta_{0}+\delta_{0}$ Post $+\beta_{1}$ Treatment $+\delta_{1}$ Post $*$ Treatment $+\beta_{2} X_{l}+I_{l}+\varepsilon$

The outcome variable, Interest $t_{l t}$, is the winning bid of lien $l$ at year $t$. The dummy variable Post is equal to one for years 2008 to 2011 when the first-price auction was conducted and zero for 2006 and 2007 when the English auction was conducted. The dummy variable Treatment represents the treatment group and is equal to one if the lien was offered in the first round and zero otherwise. The variable $\delta_{1}$, the difference-indifference estimator given by Post * Treatment, measures the effect on winning bids offered in round one after the switch to the first-price auction.

$X^{\prime}{ }_{l}$ is a vector of property characteristics for lien $l$. Property characteristics include the delinquent tax bill, estimated market value, and property type. ${ }^{3}$ I identify property type with a dummy variable indicating whether the property is residential improved or vacant. The comparison group is all other property uses including industrial vacant and commercial vacant. Tax district fixed-effects are included to control for property location.

Buyer fixed-effects, $I_{l}$, for each unique buyer name are also included. The comparison group is all liens sold to novice bidders; novice bidders participate in only one auction and purchase only one lien. Liens not purchased at auction by investors are purchased by the county at 18 percent. I treat these liens as sold to the county. This treatment avoids issues with the selection of liens sold to investors and is appropriate given the sale of unsold liens in a secondary market after auction.

Interest rates are an important determinant of the bidding strategy of buyers. The cost of capital differs by buyer and year. In order to account for these differences, buyer fixedeffects are included in the empirical model. Buyer fixed-effects are constructed by normalizing buyer name in each year and assigning a unique identifier. Therefore, all liens purchased by the same buyer in the same year have the same unique identifier. This strategy allows for the control of idiosyncratic differences in the cost of capital across buyer and year.

Table 5 presents empirically estimates for experienced bidders on the effect of a switch from English to first-price on winning bids. All specifications regress winning bids against a set of control variables, including controls for property characteristics, buyer fixed-effects, and tax district fixed-effects. The first model specification regresses winning bids for all liens offered. The second model is restricted to liens offered in the first and second round of the first-price auction and the constructed first and second

\footnotetext{
${ }^{3}$ Estimated market value of property and delinquent tax bill has been adjusted for inflation using the 2011 consumer price index as the base year.
} 
round of the English auction. The third model is restricted to liens offered in the first and third round of the first-price auction and the constructed first and third round of the English auction. The fourth model is restricted to on liens offered in the first and fourth round of the first-price auction and the constructed first and fourth round of the English auction.

The four model specifications allow the reader to examine effect of the improvement in market signals observed by bidders after each round on winning bids. The important distinction between the English and the first-price auction is that in an English auction, market signals are observed by bidders. In the first round of the first-price auction, bidders are unable to observe market signals. The market signals observed by bidders in the first-price auction improve after each round. Therefore, the first-price auction approaches an environment with same market signals observed in the English auction as the number of rounds increase.

The results from all four model specifications show average winning bids are lower in the first round of the first-price auction when compared to the control. The results are statistically significant for all specifications and range in magnitude depending on the restrictions placed on the sample. The first model specification shown in column one, using the full sample, estimates average winning bids to be 1.4 percentage points lower than the control. Recall that in an interest rate auction, lower bids represent higher prices paid by the winning bidder because the winning bid represents the interest rate bidders are willing to accept for paying the delinquent tax bill. Therefore, under the full sample winning bidders paid a price by 22 percent higher when compared to an auction environment with market signals.

The results given in columns two through four shows the effect of improvements in market signals. The second column, using restricted sample with only round one and round two results, estimates average winning bids to be 0.9 percentage points lower than the control. Therefore under the restricted sample from column two, winning bidders paid a higher price by 14 percent when compared to an auction environment with market signals. The third column, using the restricted sample with only round one and round three results, estimates average winning bids to be 1.9 percentage points lower than the control. Therefore under the restricted sample from column three, winning bidders paid a higher price by 29 percent when compared to an auction environment with market signals. The fourth column, using restricted sample with only round one and round four results, estimates average winning bids to be 1.7 percentage points lower than the control. Therefore under the restricted sample from column four, under the full sample winning bidders paid a higher price by 26 percent when compared to an auction environment with market signals.

\section{Robustness Checks}

One potential weakness of the identification strategy I use to estimate the effect of a switch from English to first-price auctions on winning bids is the treatment of liens returned to the county. It is possible that a higher number of liens returned to the county under the first-price auction would upwardly bias the estimate as liens returned to the county are charged an interest of 18 percent. 
Changing auction type, English to first-price, in a sequential common value auction does not affect a decision on whether to bid (Kagel and Levin, 2002) and therefore does not affect the probability of a lien being returned to the county. However, the first-price auction design introduces a rule which reduces the number of liens sold. It is possible to identify the causal effect of this rule on the number of liens sold at 18 percent by examining liens returned to the county in the first-price auction.

By construct liens re-offered in the first-price design at a second auction received a low bid between one percent and 18 percent by two or more bidders. In the English auction, a second auction is not needed as matching low bids between one percent and 18 percent are awarded to bidders based a random assignment. Because a second auction low bid by two or more bidders between one percent and 18 percent in the first-price auction design results in the lien being returned the county for collection, the number of liens sold is lower in the first-price auction compared to the English auction. The difference in the number of liens sold between the first-price and English auction design is equal to liens unsold in the second auction of the first-price design. Table 6 shows the total value of property tax delinquency unsold due to the change in auction type was $\$ 6.4$ million from 2008 to 2011.

In order to test the sensitivity my results to the reduced probability of sale to investors across auction types, I exclude from the sample liens returned to the county and run the basic regression model presented in equation (6). Table 7 presents the estimates of the effect of a switch from English to first-price on winning bids excluding liens returned to the county. I again present the model using four specifications. The results are consistent in significance, sign, and magnitude with those presented in table 5. The findings are not sensitive to the exclusion of liens returned to the county.

Another point of interest is the effect of learning on winning bids. It is possible that although lower bids are observed in the first round of the first-price auction across the entire period, bidders learn to avoid overpayment by bidding differently in later years after experiencing the new auction design. In order to test the sensitivity my results to learning, I restrict the sample to two time periods, one time period excluding 2010 and 2011 and another time period excluding 2008 and 2009. I rerun the basic regression model presented in equation (6) and present the results in table 8.

I again present the model using four specifications. The results are consistent in significance and sign with those presented in table 6 . The magnitude of the difference, however, does depend on the time period chosen. The results are interesting because they suggest the magnitude of the effect increasing in more recent years. The implication is that bidders are not learning across years. One possible explanation is the learning is taking place within auction by round rather than across years.

\section{Conclusion}

In this study, I test the effect of a switch from English to first-price on winning bids. I find the switch from English to first-price resulted in average winning bids to be 1.4 percentage points lower and therefore prices 22 percent higher in the first round of the first-price auction. The finding is consistent with theoretical predictions of Kagel and Levin (2002) and experimental results of Kagel and Richard (2001). Unlike Hansen 
(1986), I do not find the effect of first-price to be insignificant; suggesting that selection alone cannot explain differences in revenue.

My methodology addresses issues of selection and unobservables that can confound the effect of first-price auctions on winning bids. I argue that the difference between firstprice and English auctions is one of market signals. All market signals are observable in English auction, but this is not the case in first-price where market signals are revealed over multiple rounds. Since the first round of first-price allows for no market signals, this allows me to estimate the effect of lack of market signals under first-price by using a difference-in-difference methodology.

My findings are important on both empirical and practical grounds. On empirical grounds, I use one of the largest auction events in the country for tax lien sales. I am able to find support for the theoretical models and experimental studies by using administrative data. Similarly, my results have the potential to inform policy on auction type choice. My findings suggest that under a first-price auction investors will overpay, and that switches from English to first-price increase revenue for sellers at the expense of investor profitability.

The contribution to the literature is that this is first empirical analysis to confirm prior results while addressing potential issues of selection bias. Using a unique dataset, it is possible to observe the behavior of experienced bidders to changes in auction type across years and within auction. The results further our understanding of auction type by addressing a previously unsettled empirical result.

\section{References}

ALLEN, Marcus. T., Sheri FAIRCLOTH and Ali NEJADMALAYERI.S (2004). Factors Influencing Interest Rates on Delinquent Property Tax Certificates. Journal of Real Estate Finance and Economics 28:19-36.

ASHENFELTER, Orley. (1989). How Auctions Work for Wine and Art. Journal of Economic Perspectives 3:23-36.

ASHENFELTER, Orley. and David GENESOVE. (1992). Testing for Price Anomalies in Real-Estate Auction. American Economic Review 82:501-05.

CARLSON, T. L. (1951). The Illinois Military Tract: A Study of Land Occupation, Utilization and Tenure. Illinois Studies in the Social Sciences 32 (2), 1-218.

CONRAD, James and Larry DEBOER. (1990). The 1989 Property Tax Sale in Marion County: Results of a Survey of Investors. Unpublished Manuscript, Purdue University.

CONRAD, James, Larry DEBOER and Kevin T. MCNAMARA. (1992). Property Tax Auction Sales. Land Economics 68:72-82.

DEBOER, Larry. (1990). Property Tax Delinquency and Tax Sales: A Review of the Literature. Public Budgeting \& Financial Management 2:311-49.

KAGEL, John H. (1995). Auctions: A Survey of Experimental Rsearch in J.H. Kagel and A.E. Roth, eds., The Handbook of Experimental Economics. Princeton University Press. 501-85. 
HANSEN, R.G. (1985). Empirical Testing of Auction Theory. American Economic Review. 75:156-59.

HANSEN, R.G. (1986). Sealed-Bid versus Open Auctions: The Evidence. Economic Inquiry. 24:125-42.

KAGEL, John H. and Dan LEVIN. (2002). Common Value Auctions and the Winner's Curse. Princeton University Press.

KAGEL, John H. and J.F. RICHARD. (2001). Super-Experienced Bidders in First-Price Common Value Auctions: Rules of Thumb, Nash Equilibrium Bidding and the Winner's Curse. Review of Economics and Statistics.

KLEMPERER, Paul. (1999). Auction Theory: A Guide to the Literature. Journal of Economic Surveys 13:227-86.

KLEMPERER, Paul. (2002). What Really Matters in Auction Design. Journal of Economic Perspective. 16:169-89.

LIND, B. and C.R. PLOTT. (1991). The Winner's Curse: Experiments with Buyers and with Sellers. American Economic Review 81:335-46.

MANNING, W. G. and J. MULLAHY. (2001). Estimating log models: to transform or not to transform. Journal of Health Economics 20:461-94.

MCAFEE, R.P. and J. MCMILLAN. (1987). Auctions and Bidding. Journal of Economic Perspectives 25:699-738.

MCAFEE, R.P. and D. VINCENT. (1993). The Declining Price Anomaly. Journal of Economic Theory 60:191-212.

MEAD, W.J. (1967). Natural Resource Disposal Policy: Oral Auction versus Sealed Bid. Natural Resources Journal 7:195-224.

MENEZES, Flavio M. and Paulo Klinger MONTEIRO. (2005). An Introduction to Auction Theory. Oxford University Press.

MEZZITTI, Cluadio. (2011). Sequential Auctions with Informational Externalities and Aversion to Price Risk: Decreasing and Increasing Price Sequences. The Economic Journal 121:990-1016.

MILGROM, Paul R. and Robert J. WEBER. (1982). A Theory of Auctions and Competitive Bidding. Econometrica 50:1089-122.

MILGROM, Paul. (2004). Putting Auction Theory to Work. Cambridge University Press.

MILLER, Joshua J., and Silda NIKAJ. (2013). The Responsiveness of Tax Lien Investors in English Auctions to Matching Rules: Evidence from Illinois. Review of Regional Studies 43, no. 1.

SWIERENGA, R. P. (1974). Acres for Cents: Delinquent Tax Auctions in Frontier Iowa. Agricultural History 48 (2), 247-266.

U.S. Department of Justice. (August 24, 2011). Three New Jersey Investors Plead Guilty to Bid Rigging at Municipal Tax Lien Auctions. 
Tables

\begin{tabular}{|c|c|c|c|c|c|c|}
\hline \multicolumn{7}{|c|}{ TABLE 1 - Auction Descriptive Statistics I } \\
\hline & \multicolumn{6}{|c|}{ Illinois - Cook County - 2006 to 2011} \\
\hline & \multicolumn{3}{|c|}{ Sold } & \multicolumn{3}{|c|}{ Unsold } \\
\hline & No. Liens & $\begin{array}{c}\text { Mean } \\
\text { Delinquent } \\
\text { Tax Bill } \\
(\$) \sim\end{array}$ & $\begin{array}{l}\text { Percent } \\
\text { Residential } \\
\text { Improved }\end{array}$ & No. Liens & $\begin{array}{c}\text { Mean } \\
\text { Delinquent } \\
\text { Tax Bill } \\
\text { (\$) }\end{array}$ & $\begin{array}{l}\text { Percent } \\
\text { Residential } \\
\text { Improved }\end{array}$ \\
\hline English & 38198 & $\$ 2688$ & $76,7 \%$ & 6902 & $\$ 2623$ & $12,7 \%$ \\
\hline First-Price Sealed-Bid & 90722 & $\$ 3613$ & $81,5 \%$ & 36895 & $\$ 2937$ & $35,7 \%$ \\
\hline$\sim$ Adjsuted for inflation & esented in & $011 \$$ & & & & \\
\hline
\end{tabular}

\section{TABLE 2 - Auction Descriptive Statistics II}

\begin{tabular}{|c|c|c|c|c|c|c|}
\hline & \multicolumn{6}{|c|}{ Illinois - Cook County - 2006 to 2011} \\
\hline & \multicolumn{2}{|c|}{ No. Liens } & \multicolumn{2}{|c|}{ Tax Delinquency } & \multicolumn{2}{|c|}{$\begin{array}{c}\text { Winning Interest } \\
\text { Rate* }^{*}\end{array}$} \\
\hline & Offered & $\begin{array}{l}\text { Percent } \\
\text { Sold to } \\
\text { Private }\end{array}$ & Offered & $\begin{array}{l}\text { Percent } \\
\text { Sold to } \\
\text { Private }\end{array}$ & Mean & Median \\
\hline English & 45100 & $84,7 \%$ & $\$ 120763,7$ & $85,0 \%$ & 3,9 & 0,0 \\
\hline First-Price Sealed-Bid & 127617 & $71,1 \%$ & $\$ 436148,5$ & $75,2 \%$ & 7,4 & 3,0 \\
\hline
\end{tabular}




\section{TABLE 4 - Auction Descriptive Statistics IV}

First-Price Sealed-Bid

Round 1

Round 2

Round 3

Round 4

English

\begin{tabular}{llc} 
Constructed - Round 1 & $7,07 \%$ & $5,86 \%$ \\
Constructed - Round 2 & $6,40 \%$ & $3,83 \%$ \\
Constructed - Round 3 & $2,13 \%$ & $1,32 \%$ \\
Constructed - Round 4 & $1,29 \%$ & $0,66 \%$ \\
\hline
\end{tabular}

$\sim$ For the English auctions, I assign liens to rounds based on property location. The assignment is consistent the assignment of liens under first-price auctions. Therefore, had the English liens been sold under the first-price the round assignment would have been the same. 
TABLE 5 - Empirical Results - Difference-In-Difference Illinois - Cook County - 2006 to 2011

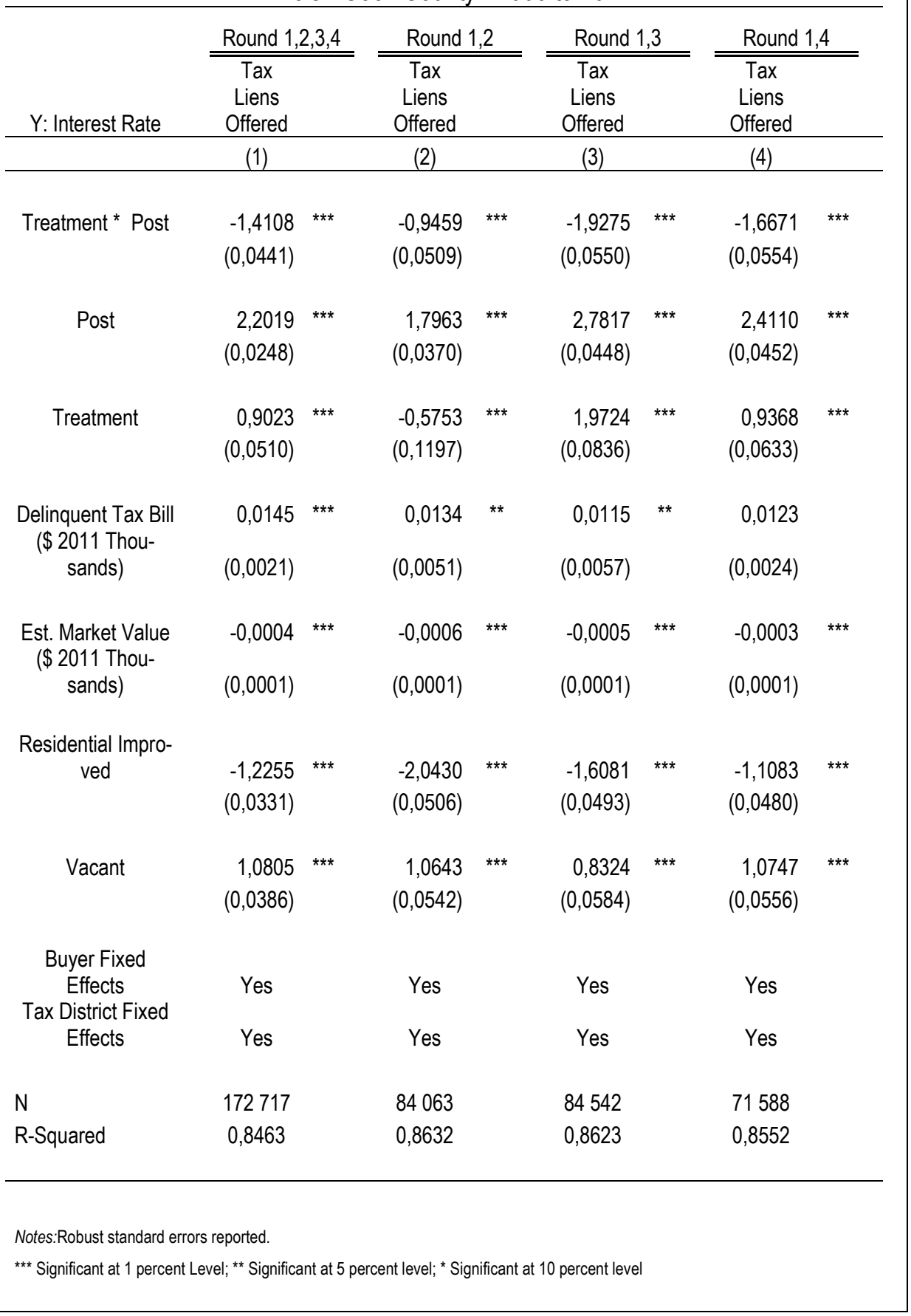


TABLE 6 - Tax Liens Reofferd and Unsold in the First Price Sealed Bid Second Round

\begin{tabular}{|c|c|c|c|c|}
\hline \multirow[b]{3}{*}{ Year } & \multicolumn{4}{|c|}{ Illinois - Cook County } \\
\hline & No. Liens & $\begin{array}{l}\text { ax Delinquency } \\
\sim\end{array}$ & Percent & Mean \\
\hline & Unsold & Unsold & $\begin{array}{l}\text { Residential } \\
\text { Improved }\end{array}$ & $\begin{array}{c}\text { Delinquent Tax } \\
\text { Bill }\end{array}$ \\
\hline 2008 & 53 & $\$ 380815$ & $49,1 \%$ & $\$ 7185$ \\
\hline 2009 & 1053 & $\$ 5787084$ & $93,8 \%$ & $\$ 5496$ \\
\hline 2010 & 144 & $\$ 104312$ & $74,3 \%$ & $\$ 7244$ \\
\hline 2011 & 232 & $\$ 130017$ & $83,6 \%$ & $\$ 5604$ \\
\hline Total & 1482 & $\$ 6402228$ & $88,7 \%$ & $\$ 5743$ \\
\hline
\end{tabular}




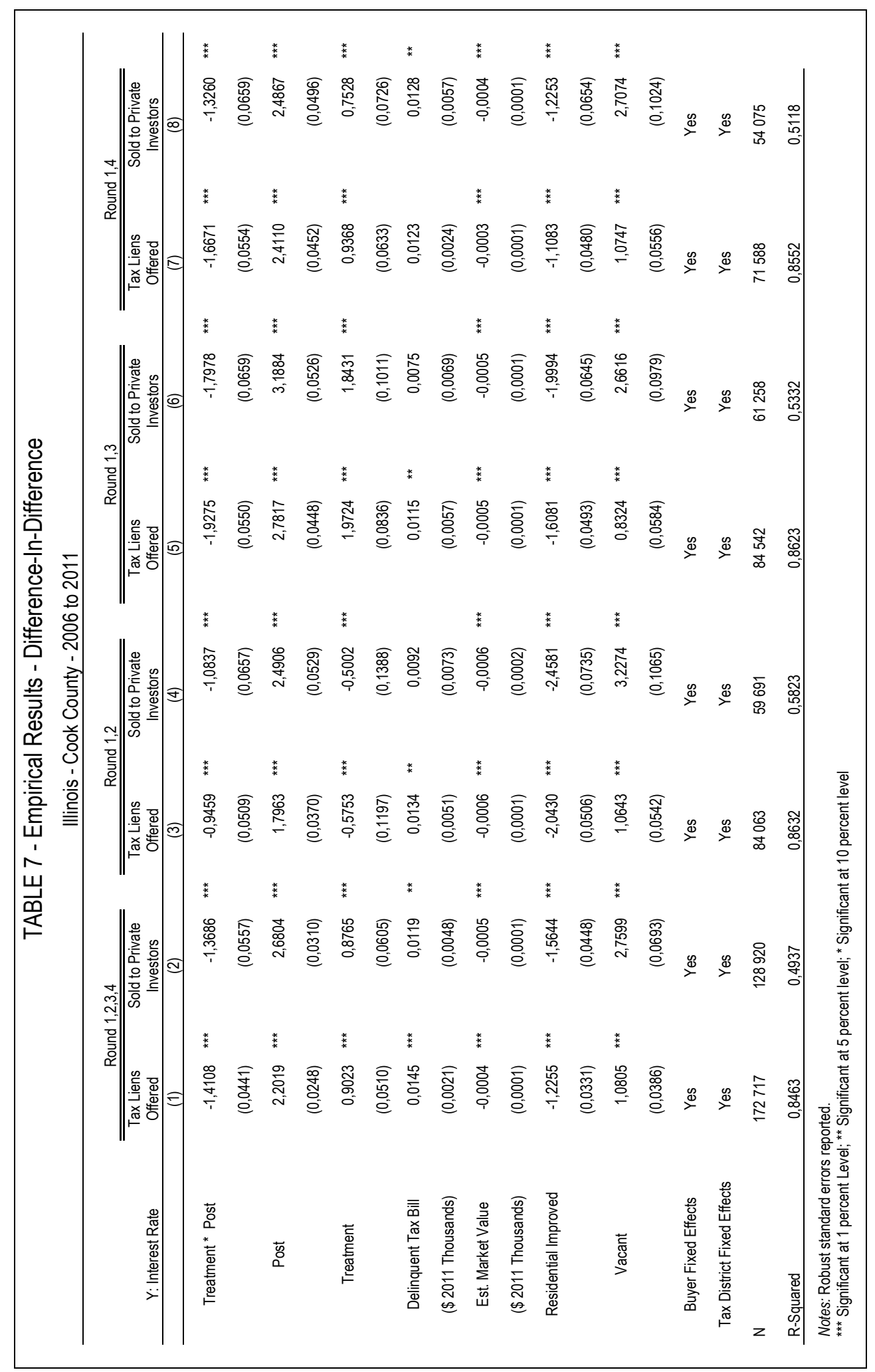




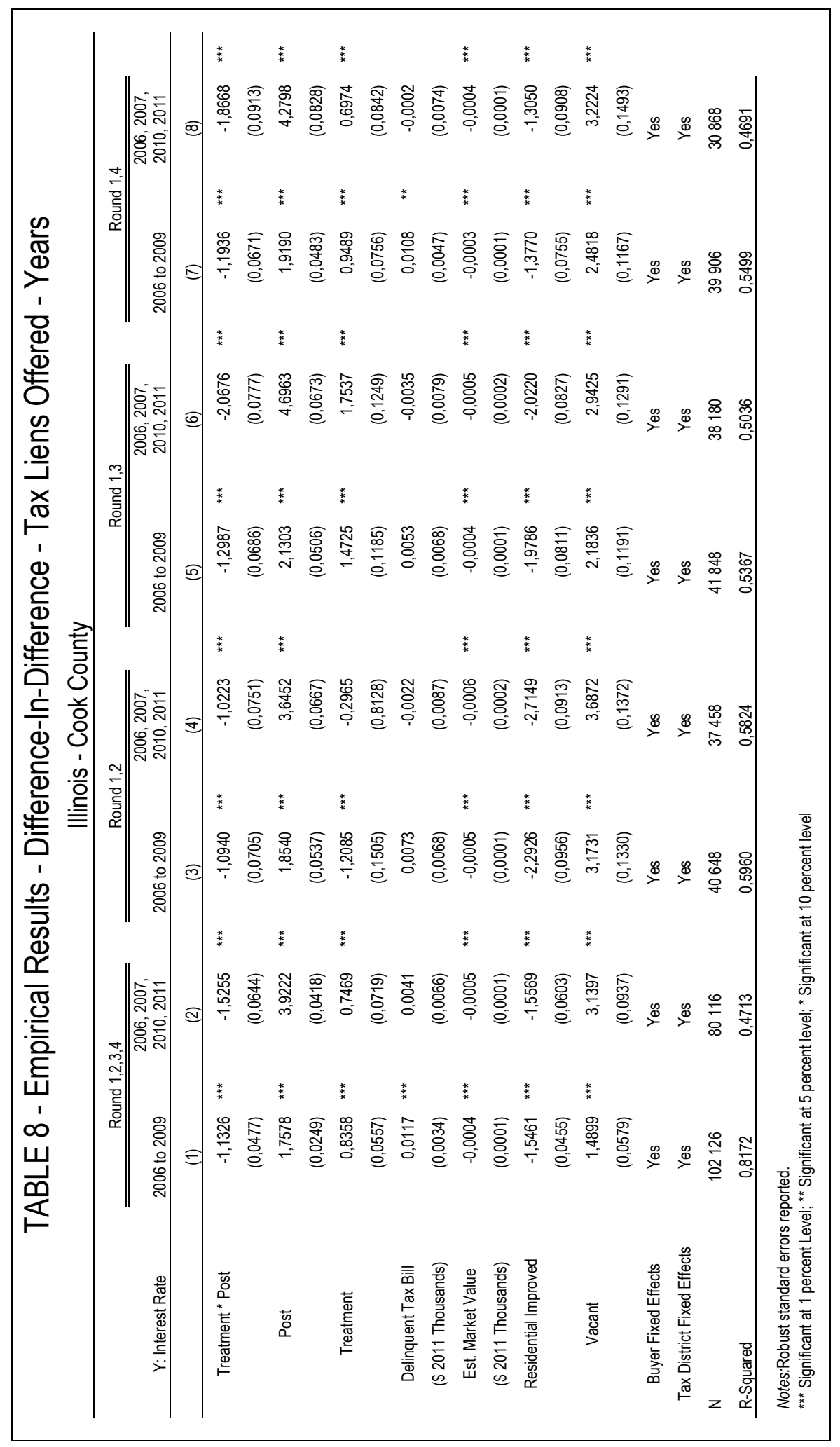


Figure 1

Tax Lien Sale Results

2006 to 2011

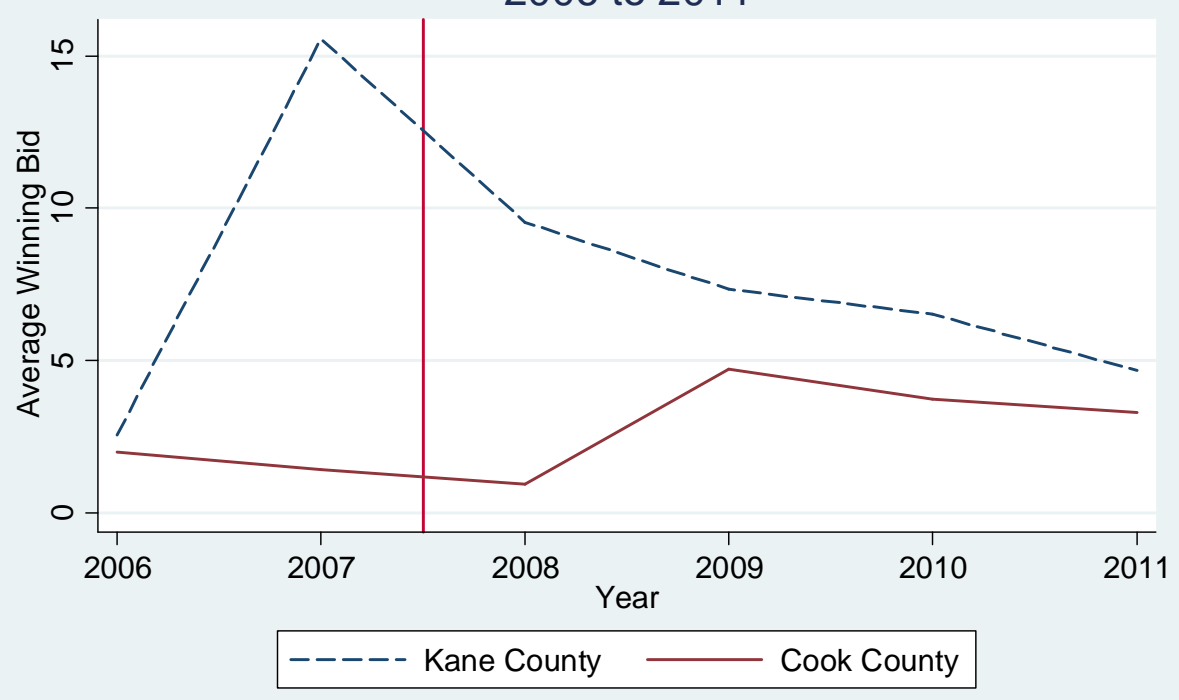

